\title{
Precipitation Patterns in Cape Verde Islands: Santiago Island Case Study
}

\author{
Gerson Ernesto Varela-Lopes, Luiz Carlos Baldicero Molion \\ Atmospheric Science Institute, Federal University of Alagoas, Maceió, Brazil \\ Email: gbrunoj@hotmail.com
}

Received 6 September 2014; revised 20 October 2014; accepted 17 November 2014

Copyright (C) 2014 by authors and Scientific Research Publishing Inc.

This work is licensed under the Creative Commons Attribution International License (CC BY).

http://creativecommons.org/licenses/by/4.0/

(c) (i) Open Access

\section{Abstract}

The Cape Verde archipelago is located between $14^{\circ} \mathrm{N}-18^{\circ} \mathrm{N}$ and $22^{\circ} \mathrm{W}-28^{\circ} \mathrm{W}$ in the Atlantic Ocean. Previous studies associated Cape Verde's rainfall regime with ITCZ and African squall lines. This hypothesis is revisited here using rainfall time series of the 4 Santiago Island station network of Cape Verde National Institute of Meteorology and Geophysics. Rainfall monthly totals are standardized to produce indices in the 1981-2009 period. Time section plots of zonal and meridional wind components anomalies are made using reanalysis data from ESRL/PSD/NOAA website. Daily outgoing long wave radiation and sea level pressure time section plots are also made as proxies for weather systems propagation. Results show that Santiago presents a seasonal rainfall regime characterized by dry (November-June) and wet (July-October) seasons, with short transition period. In general, rainfall totals increase with altitude. Weather systems within a wet year rainy season were associated with positive anomalies of zonal and meridional wind components of relative short duration, while negative anomalies dominated in dry years. These results suggest that winds coming from southwestern quadrant over warm Atlantic Ocean, associated with frontal systems traveling eastward, are the rain-producing events in wet years, not ITCZ or African squall lines. Winds coming from the northeastern quadrant produce dry years. Apparently, decadal-long wet periods are related to PDO cold phase. In the current PDO cold phase, there is only one year (2002) slightly dry. Considering that each PDO phases lasts 25 to 30 years and the current PDO cold phase started in 1999, it is possible that wet years predominate in the next 10 to 15 years.

\section{Keywords}

ITCZ, El Niño, PDO, OLR, Zonal and Meridional Winds

\section{Introduction}

Cape Verde Islands are located off the West African coast between $14^{\circ} \mathrm{N}-18^{\circ} \mathrm{N}$ and $22^{\circ} \mathrm{W}-28^{\circ} \mathrm{W}$ in North At- 
lantic Ocean. The islands lie $570 \mathrm{~km}$ off the Senegal coast and constitute an archipelago of volcanic origin, composed by ten islands-nine inhabited islands and one uninhabited-which together have a $4.033 \mathrm{~km}^{2}$ land cover surface. According to [1], it is inserted on the Sahel climate zone-arid and semi-arid-crossing Africa from Atlantic to Red Sea, and it extends from Saudi, Syria and Mesopotamia, to temperate deserts zone of Eurasia and subdesert regions. These areas are strongly affected by monsoon climates.

Air temperature is around $20^{\circ} \mathrm{C}$ in most of country in coldest period from January to April and reaches values higher than $27^{\circ} \mathrm{C}$ in hottest period, from August to October. Annual rainfall varies from less than $100-150 \mathrm{~mm}$ on arid flat coastal to around 800 - $900 \mathrm{~mm}$ in highest mountainous areas above $1000 \mathrm{~m}$ elevation. Cape Verde climate is governed by a strong diurnal cycle and the annual cycle by West African monsoon circulation with two different wind regimes [2].

With regard to systems that affect the archipelago's climate, it is noteworthy the variable wind regime throughout the year. Northeast trade winds predominate, blowing strongly between December and May. Past studies suggest that Intertropical Convergence Zone (ITCZ) affects directly Cape Verde's climate. ITCZ presence over Cape Verde's latitudes is, however, negatively affected by pressure fluctuations of Azores anticyclone and other high altitude air mass fluxes in northern Central Atlantic [3]. An extremely variable rainfall regime results from oscillations of this regional high and low pressure zones. The archipelago may be affected by squall lines or tropical disturbances that originate over the African Continent. These phenomena are well described in [4].

West Africa rainfall, on the other hand, has been subject of many studies and research due to the location of various countries in the Sahel region and the extreme variability of precipitation in those areas. Sahel, extending across Africa from Atlantic Ocean to Indian Ocean, is the largest semiarid region of world. Studies vary from seasonal systems of active precipitation to seasonality (i.e., duration of the dry and wet season) and possible trends of these variations.

A classical and dominant feature of atmospheric dynamics in the tropics is the ITCZ, characterized by a belt of low-level trade winds convergence and upper-level divergence with strong updrafts, deep convection, frequent cloudiness, and heavy rainfall [5]. Past and modern studies have suggested an influence of the ITCZ in the rainfall over West Africa (e.g., [6]-[8]).

A study by [9] computed radiosonde data averages for 11 year period (1960-70) of eight stations located along latitude of $5^{\circ} \mathrm{N}$ representing the monsoon belt, and others around $13^{\circ} \mathrm{N}-14^{\circ} \mathrm{N}$, a typical zone of semiarid climatic regime (i.e., southern and northern zones, respectively). Authors mentioned that northern climate is affected by the surface ITCZ's excursion and the intrusion of mid-latitude westerlies.

Annual rainfall long-term series for 69 stations throughout the entire African continent including a Cape Verde station-Sao Vicente Island (Mindelo at $16^{\circ} 53^{\prime} \mathrm{N}, 25^{\circ} 00^{\prime} \mathrm{W}$ )—were examined [10]. Results show a generally oscillatory trend at beginning followed by a negative trend. He found that, overall, no significant trends or periodicities were evident, although the oscillatory characteristic is present in most data analyzed.

It was pointed out that, during boreal summer when ITCZ moves northward with increasing solar declination, a heat low is generated over Sahara Desert. Moist southwesterly winds at surface and African easterly jet in middle troposphere are dominant over the continent [8].

The rainfall variability in the Western Sahel was studied using a long-term dataset in the period between 1950 and 2004 for 14 stations of 6 countries in West Africa Sahel area (Niger, Mali, Mauritania, Burkina Faso, Benin, and Senegal-located in close proximity of Cape Verde) [11]. The results present solid evidence associating the rain regime to the period the ITCZ reaches its maximum position in its movement to the north, and more intense activity of a classical SW monsoon. The study also indicates that oscillatory movement of the ITCZ is a signature of the same phenomenon for the dry regime when the ITCZ migrates to the south, and its influence is experienced over the transition regime.

The Cape Verde population has increased $40 \%$ over the past 20 years, reaching about half million inhabitants, and definitely it will continue to increase in the near future. Water resources, both for human and animal consumption, as well as crop cultivation, are scarce and already a limiting factor for society welfare at present. As opposed to West Africa, the Cape Verde rainfall regime, and its relationship with large scale atmospheric phenomena, has never been studied in details. Due to its geographical location and proximity to the Sahel, it always has been supposed to behave like West Africa's. The Santiago Island is selected for this case study since it has available a reliable 29-year period rainfall data set of four gauges of the Cape Verde National Institute of Geophysics and Meteorology (INMG, in Portuguese) network and it is more vulnerable because it holds more than 
$50 \%$ of the country's population. These observed data sets in conjunction with the NCEP/NCAR reanalysis data set are used to characterize its rainfall regime and to identify apparent climate cycles and possible large scale atmospheric mechanisms that are responsible for its rainfall production, in particular the hypothesis that the ITCZ is the main rainfall producing mechanism. It is expected that the results presented here will contribute to better rainfall forecasting, both in the short and long ranges, that, in turn, will help to develop and implement policies and strategies for water resources usage in the Archipelago.

The analysis is presented as follows. Section 2 describes the data and methods used in this investigation. A descriptive characterization of rainfall patterns of Santiago over the study period is presented in Section 3, examining long-term seasonality and possible rain-producing systems. Summary and conclusion follow in Section 4.

\section{Data and Methodology}

\section{Study Area}

Santiago $\left(14^{\circ} 54^{\prime}-15^{\circ} 20^{\prime} \mathrm{N} ; 23^{\circ} 25^{\prime}-23^{\circ} 46^{\prime} \mathrm{W}\right)$ is the largest island in the archipelago and its most significant agricultural center with an area of $991 \mathrm{~km}^{2}$. According to their geopolitical characteristics, the Island is divided into 6 key municipalities, as shown in Figure 1. The Island is characterized by scarce hydrologic resources due to the low and irregular rainfall totals (average $321 \mathrm{~mm} /$ year in the highest mountains and about $169 \mathrm{~mm} /$ year at low levels) and also that this fact is responsible for some quasi-periodic and catastrophic dryness. The small amount of superficial water combined with irregular precipitation explains the strong dependence of the population on subterranean water [12]. Studies on water balance indicate that runoff takes $18 \%$ of precipitation and it is directly discharged to the sea, and approximately $13 \%$ infiltrates the soil. The remaining water is lost by evapotranspiration, which attains a mean annual potential value of $1500 \mathrm{~mm}$ [13]. Despite the low rainfall values, very intensive rain events, together with the topography effect, lead to flood at most of the existent creeks [14].

Praia City is the capital of Cape Verde and concentrates most of the country's population. Santiago's climate is conditioned by its geomorphology [15]. As a result of the altitude, it is noted that, moving within the Island, the arid coastal zone climate type becomes semi-arid, and finally sub-humid, as shown in Table 1 . These characteristics strongly define the main agricultural products (e.g., corn, sugar cane, banana, coffee and mangoes).

Rainfall data sets from four stations of the INMG were used for this analysis. The length of the records is the same for all rainfall series examined. Santiago Island long-term rainfall data permitted a regional analysis to examine the variation in the rainfall patterns for the 29-year period 1981-2009. Data records were from 3 meteorological stations and 1 rain gauge station set up according to the World Meteorological Organization standards. Figure 1(c) displays the geographical distribution of weather stations used and Table 2 summarizes the

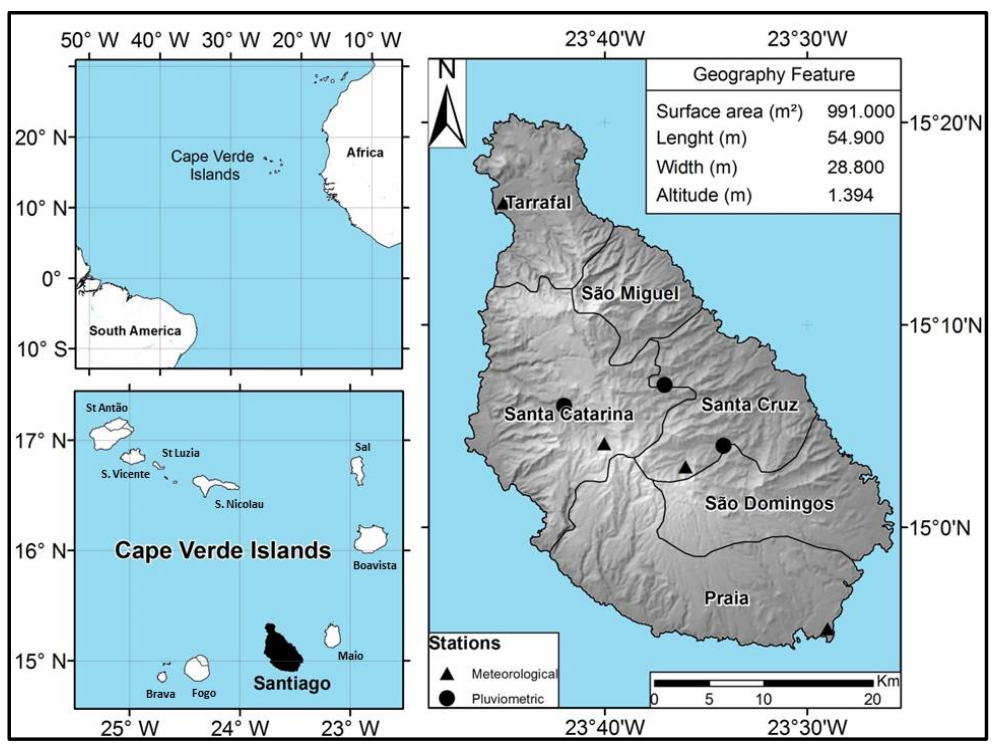

Figure 1. Cape Verde localization (a) West Africa; (b) Santiago Island; (c) Stations distribution. 
Table 1. Santiago Island main climate zones considering altitude and rainfall values.

\begin{tabular}{ccc}
\hline Climate Zone & Altitude $(\mathrm{m})$ & Precipitation (mm) \\
Arid & $<100$ & $<250$ \\
Semi-arid & $100-200$ & $250-400$ \\
Sub-humid & $200-500$ & $400-500$ \\
Humid & $>500$ & $>500$ \\
\hline
\end{tabular}

Table 2. Santiago Island stations' location, elevation, length of data record.

\begin{tabular}{ccccc}
\hline Station & \multicolumn{2}{c}{ Location } & Elevation $(\mathrm{m})$ & Record length \\
\hline Airport $^{1}$ & $14^{\circ} 54^{\prime} \mathrm{N}$ & $23^{\circ} 28^{\prime} \mathrm{W}$ & 64 & $1981-09$ \\
Babosa Picos $^{2}$ & $15^{\circ} 07^{\prime} \mathrm{N}$ & $23^{\circ} 37^{\prime} \mathrm{W}$ & 454 & $1981-09$ \\
Chão Bom $^{1}$ & $15^{\circ} 16^{\prime} \mathrm{N}$ & $23^{\circ} 45^{\prime} \mathrm{W}$ & 16 & $1981-09$ \\
São Jorge dos Orgãos & $15^{\circ} 03^{\prime} \mathrm{N}$ & $23^{\circ} 36^{\prime} \mathrm{W}$ & 310 & $1981-09$ \\
\hline
\end{tabular}

${ }^{1}$ Meteorological station; ${ }^{2}$ Rain gauge station.

stations' information.

It has been common practice to assume that at least ten years of daily observations are necessary to produce the relevant base statistical parameters for most meteorological elements, and at least thirty years for precipitation [16]. Simple descriptive statistics for measured monthly, seasonal, and annual rainfall were calculated for the period from 1981 to 2009 for the gauges with continuous records. To summarize the rainfall changes over the study period, a rainfall index was also used by standardizing the time series of four stations with the $29 \mathrm{yr}$ of data according to [17]:

$$
x_{i, j}=\frac{\left(p_{i, j}-\mu_{i}\right)}{\sigma_{i}}
$$

where $x_{i, j}$ is the standardized monthly rainfall deviations; $p_{i, j}$ is the annual rainfall for the Island; $\mu_{i}$ is the mean value of 1981-2009 period; and the $\sigma_{i}$ the standard deviation 1981-2009 period. This index allows to highlight driest and wettest years over all the period. Time versus longitude plots of zonal (U) and meridional (V) wind components anomalies (Operational Data Plot $-2.5^{\circ} \times 2.5^{\circ}$ resolution) for the $850 \mathrm{hPa}$ level over the region are made using reanalysis data from ESRL/PSD/NOAA website. The variables are averaged over $5^{\circ}$ latitudinal strip, from $12.5^{\circ} \mathrm{N}-17.5^{\circ} \mathrm{N}$, and the longitudinal range of $0^{\circ} \mathrm{W}$ to $60^{\circ} \mathrm{W}$ is in the horizontal axis. These anomalies were used to observe the wind pattern dominance during dry and wet years (i.e., humid winds from Atlantic Ocean and dry air from Sahara desert region). An accurate description of the NCEP/NCAR Reanalysis project can be found in [18]. A large subset of these data is available from ESRL in its original format of 6 hour intervals and daily average analyses. The project uses a state-of-the-art analysis/forecast system to perform data assimilation using past data from 1948 to the present. These data are selected because of it is the best data set available at present moment, for its free availability and easy access.

Data of daily outgoing longwave radiation anomalies (OLR) are often used asproxy of areas of tropical convection and to estimate the earth's radiation budget. In this study, daily OLR time versus longitude section plots are made to track possible weather systems or traveling disturbances over Santiago Island. OLR data are averaged for latitudinal belt $12.5^{\circ} \mathrm{N}-17.5^{\circ} \mathrm{N}$ and extend from $0^{\circ} \mathrm{W}$ to $60^{\circ} \mathrm{W}$ of longitude. For more details about OLR anomalies description read [19], for example. Time sections of sea level pressure (SLP) are also elaborated over the same geographic domain as a support for the OLR anomaly analysis. The OLR and SLP data are taken from ESRL/PSD/NOAA. Time section plots are made with the applets existing in the same website. Lastly, 2 years, the driest year (1994) and the wettest one (1999) in the record are selected for analyzing the atmospheric phenomena that generate wet years and dry years.

\section{Results and Discussion}

\subsection{Seasonal Variability}

In general, Santiago presents a seasonal rainfall regime characterized by two distinct periods: dry and rainy sea 


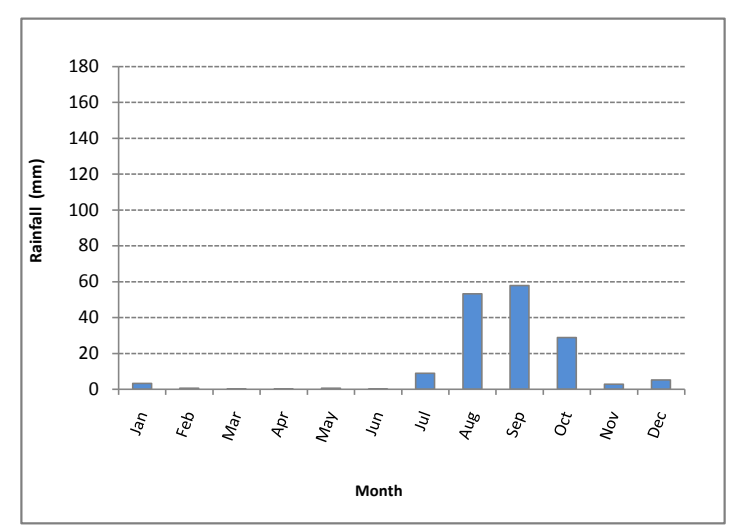

(a)

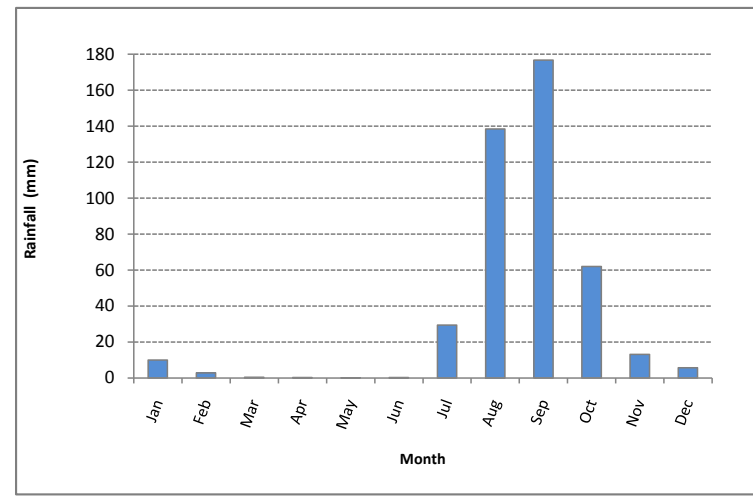

(c)

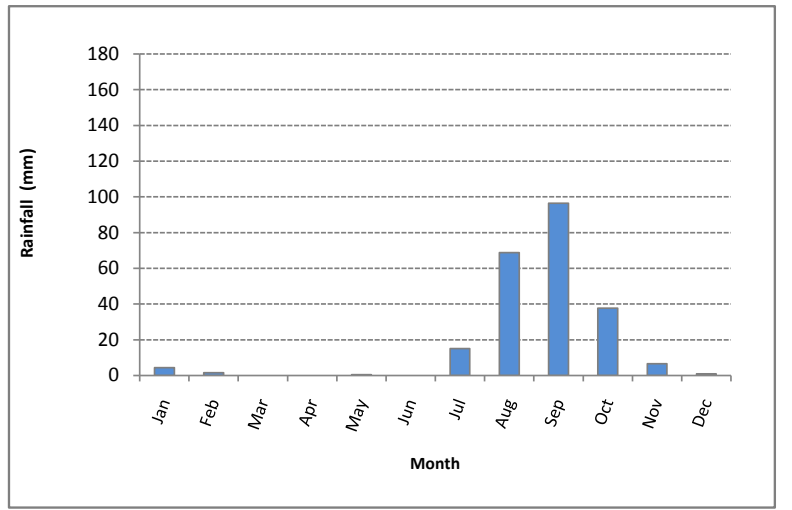

(b)

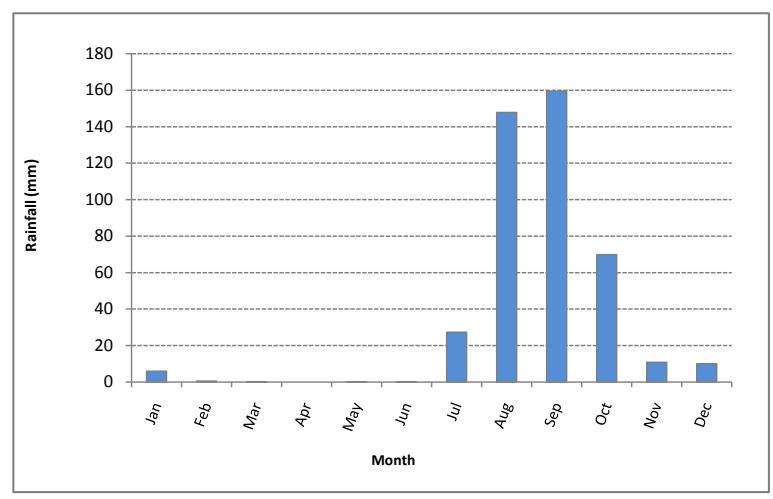

(d)

Figure 2. Average monthly rainfall distribution for the period of 1981-2009 for (a) Airport; (b) Chão Bom; (c) São Jorge dos Orgãos; and (d) Babosa Picos.

sons. The average monthly distribution of rainfall is shown in Figure 2. As illustrated, the dry season corresponds to the months November to June. Despite the fact this period is considered as dry, sporadic precipitation occurrence is common, mostly from November to January referred to as transition months when remnants of cold fronts reach the archipelago. The months of April and June were considered as the driest months in some cases without any precipitation recorded for the entire study period, except São Jorge dos Orgãos that it is the only station with rainfall throughout the year. During the dry period, the maximum precipitation value registered was 13 and 10 $\mathrm{mm}$, corresponding to the month of November for S. Jorge dos Orgãos and Babosa Picos stations, respectively.

In contrast, the rainy period corresponds to the north hemisphere warmer months (i.e., from July to October), the month of September standing out as the wettest month, with values between $60-100 \mathrm{~mm}$ for Airport and Chão Bom, and values greater than $150 \mathrm{~mm}$ for S. Jorge dos Orgãos and Babosa Picos. The two last-mentioned stations are located in strategic regions considered to have large agricultural potential, consequently, of great economic importance.

Soil erosion values derived from a 7-year (1980-1987) rainfall recording in Santiago Island are analyzed by [14]. The dataset consisted of 63 storms events, continuously registered at 15-min intervals. Results from two stations located nearby the Airport station (i.e., Achada das Vacas- $14^{\circ} 59^{\prime} \mathrm{N}, 23^{\circ} 32^{\prime} \mathrm{W}, 220 \mathrm{~m}$; and Trindade$14^{\circ} 57^{\prime} \mathrm{N}, 23^{\circ} 34^{\prime} \mathrm{W}, 210 \mathrm{~m}$-added for better comparison) indicate a short rainy season from August to October with fluctuating values (highest values ranged from 40 - $45 \mathrm{~mm}$ for September, the wettest month). Their results are very consistent when compared to the present study which presents the highest values ranging $40-55 \mathrm{~mm}$ for the same area.

Airport and Chão Bom present the lowest while S. Jorge dos Orgãos and Babosa Picos the highest rainfall totals as it can be seen in Figure 3. This result can be directly related to the elevation, as these stations are located in the highest places of the Island. The steep topography of the Island enhances the systems convection and air masses passing over it (orographic effect). It is interesting to note that the wetter months generally exhibit great- 


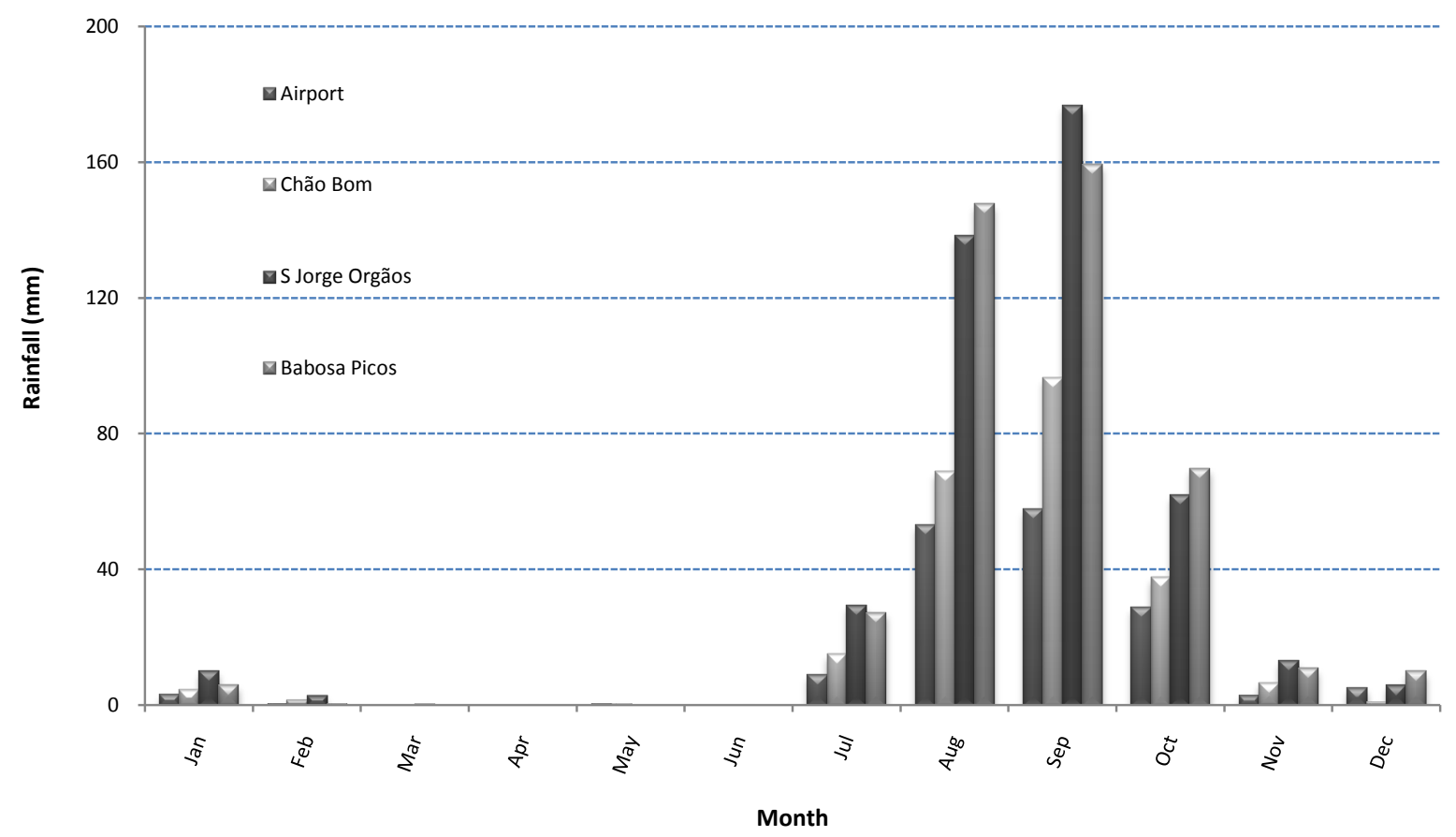

Figure 3. Average monthly rainfall distribution for the period of 1981-2009 for 4 gauges of Santiago Island.

er rainfall variability.

These results show that Santiago Island rainfall present a strong intra-seasonal variability. This knowledge should provide useful information to governmental and private projects involving design of hydrologic structures such as barrages, water supply and irrigation dams, relevant to the region.

\subsection{Long-Term Variability}

Figure 4 presents the results of the standardized rainfall index time series computed for Santiago Island stations network for the existing data period 1981 to 2009. In this graph, year totals within the \pm 1 horizontal lines, that is, tone standard deviation, are considered “normal” years. In general, anomaly modules in wet years are higher than in dry years. Two distinct periods are considered according to the Pacific Decadal Oscillation (PDO) phases. The first period, spanning from 1981-1998, is within the PDO warm phase. The years 1987 and 1994 are two El Niño years according to the CPC/NOAA's Oceanic Niño Index (ONI), and they are the wettest and driest years within this period, respectively. A sequence of years near or below the average rainfall total (zero line) is seen from 1989 to 1998 (10 years), with the years of 1994, 1996 and 1998 being of severe drought. In fact, during this whole 18 year period, rainfall is below average in 12 years and only in 2 years (11\%) it is in excess of one standard deviation. The results are consistent and similar to [20] for West Africa. In their study, it is mentioned that, during most of the 1990's, major part of the Sahel suffered from extreme drought that affected some Sahelian coastal capitals, like Abidjan and Cotonou, with a shortage of electricity due to the closure of some hydropower plants. The second period, 1999 and 2009, is in the current PDO cold phase. In contrast to the previous one, this period is characterized by 7 rainy years out of 11 years $(64 \%)$, including the wettest year of whole period studied, the year 1999 (strong La Niña), seconded by 2003 (El Niño). The year 2002, an El Niño event, was the driest year within this period, but with less than one standard deviation departure. Apparently, there are no drought conditions during the current PDO cold phase yet. Unfortunately, there is no data available for comparison with the previous PDO cold phase, 1946-1976. The above results indicate that, besides having a marked intraseasonal variation, there is strong inter-annual variability in the Santiago Island rainfall but it is not related to the El Niño-Southern Oscillation (ENSO) phenomenon.

The results also suggest there is an inter-decadal variability that may be related to PDO. Dry years dominated during its warm phase, whereas there is only one relatively dry year since the beginning of the current PDO cold phase in 1999. 


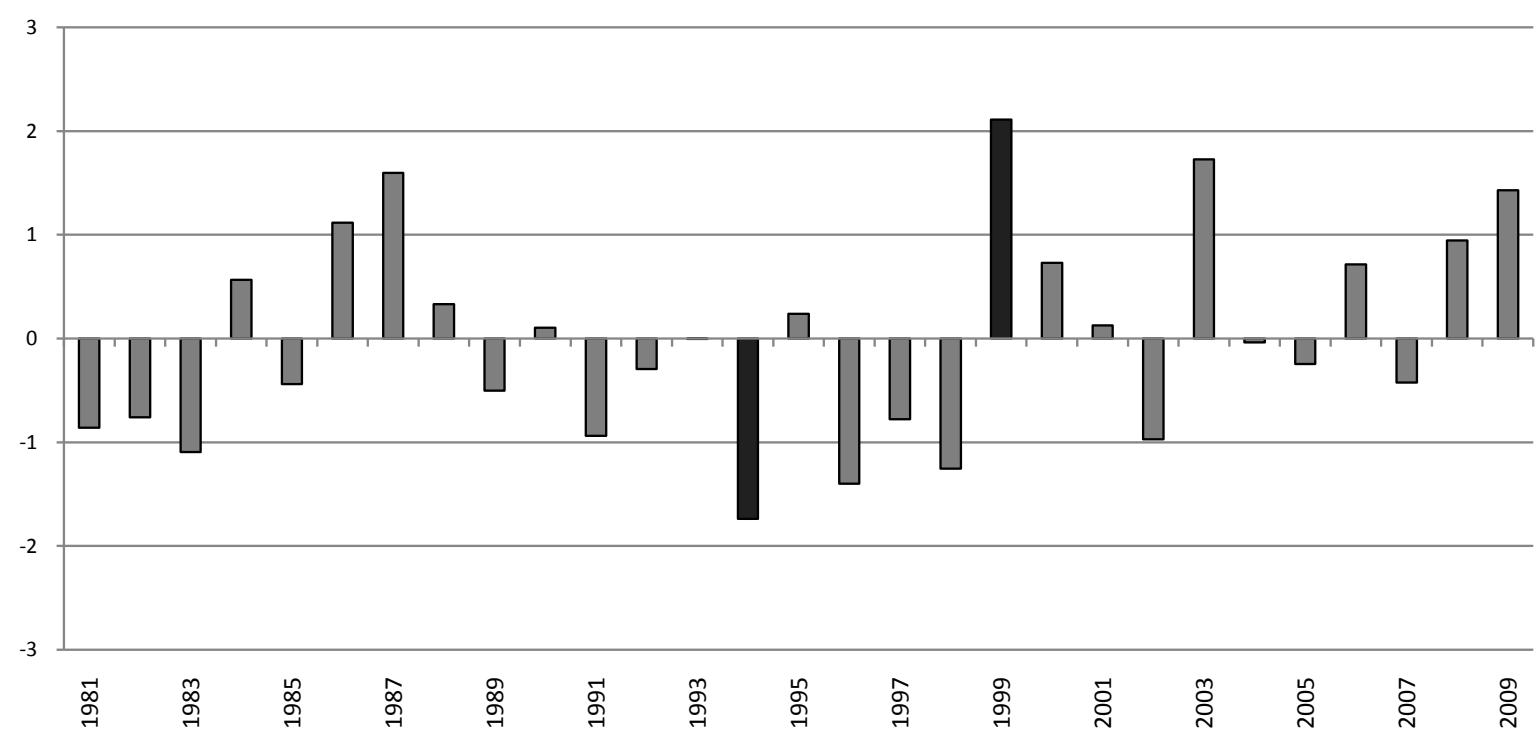

Figure 4. Time evolution of the standardized rainfall index for Santiago Island between 1981 and 2009.

Another oscillation that may possibly influence Cape Verde longer-term rainfall variability is the North Atlantic Oscillation (NAO). This oscillation exhibits considerable inter-seasonal and inter-annual variability between its positive and negative phases. It may remain locked in one phase for long periods (several months), changing the weather patterns from North America to Europe across the Atlantic for several years. For example, its negative phase predominated from the mid-1950 to 1978/79 boreal winter. After that, NAO is locked in the positive phase until the 1994/95 winter and then it returns to the negative phase until present. During its negative phase, storm tracks are displaced southward, bringing more moist air into southern Europe and northern Africa. It is interesting to note that dry (wet) years are frequent in its positive (negative) phase in Santiago records (Figure 4). The possible relationship between NAO and Cape Verde rainfall variability deserves a deeper investigation.

\subsection{Wetness and Dryness Producing Systems}

As seen in Figure 4, the driest and rainiest years for the entire period are 1994 and 1999, respectively. A more detailed study of these two years is made with the objective of finding possible large-scale atmospheric mechanisms setting up wet and dry years.

Figure 5 presents the OLR anomaly longitude versus time plots used to identify the presence of convective activity over the region of study, for the time period July to October (rainy season), in these two years. It is possible to observe the displacement of convective systems coming from the Central Africa region ( $\left(0^{\circ}\right.$ longitude) moving westward, passing over Cape Verde (location represented by the dashed vertical line). This pattern of movement was more intense and persistent for 1999, the rainiest year, than for 1994, considered the driest year.

During the year of 1999, the OLR anomaly field indicates enhanced atmospheric convection associated with precipitation in this region, since OLR anomaly values are ranging from -35 to $-80 \mathrm{~W} \cdot \mathrm{m}^{-2}$. In Figure 5 (b), it can be seen that the frequency of slanted blue tracks (negative anomalies) from July 1 to October 31st is high. At least 14 systems traveled over the Archipelago. In 1994 (Figure 5(a)) on the other hand, OLR anomaly field indicates low convective activity as fewer blue tracks are seen. Since the months of August and September are responsible for over 70\% of total precipitation (Figure 3), decrease in the intensity of active weather systems leads to decrease the rain accumulation in the region. This change was observed during the year of 1994 (Figure 5(a)) from mid-August to the end of September, producing the driest year of the record.

Analysis of Figure 5 indicates that traveling disturbances are an important mechanism that produces rain in Cape Verde. The inclination of the dashed lines suggests that they travel westward at a rate of $3^{\circ}$ to $5^{\circ}$ longitude per day over the ocean, consistent with results found in the literature.

On the monthly mean, the absolute value of the sea level pressure (SLP) barely changes because the region is 


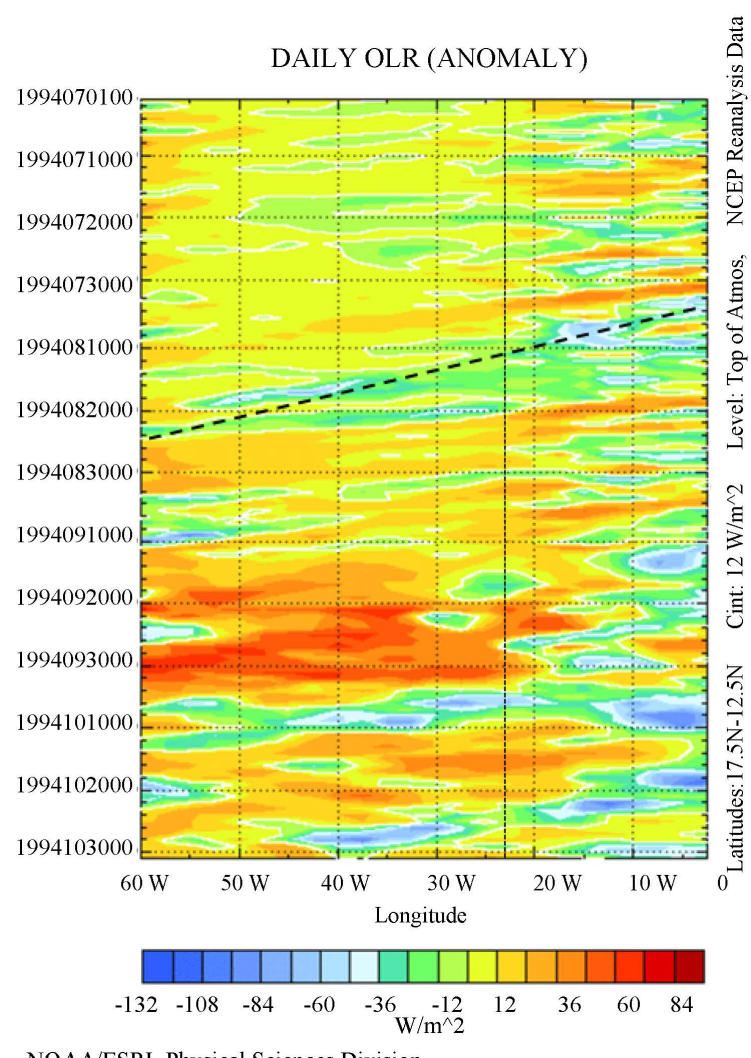

NOAA/ESRL Physical Sciences Division

(a)

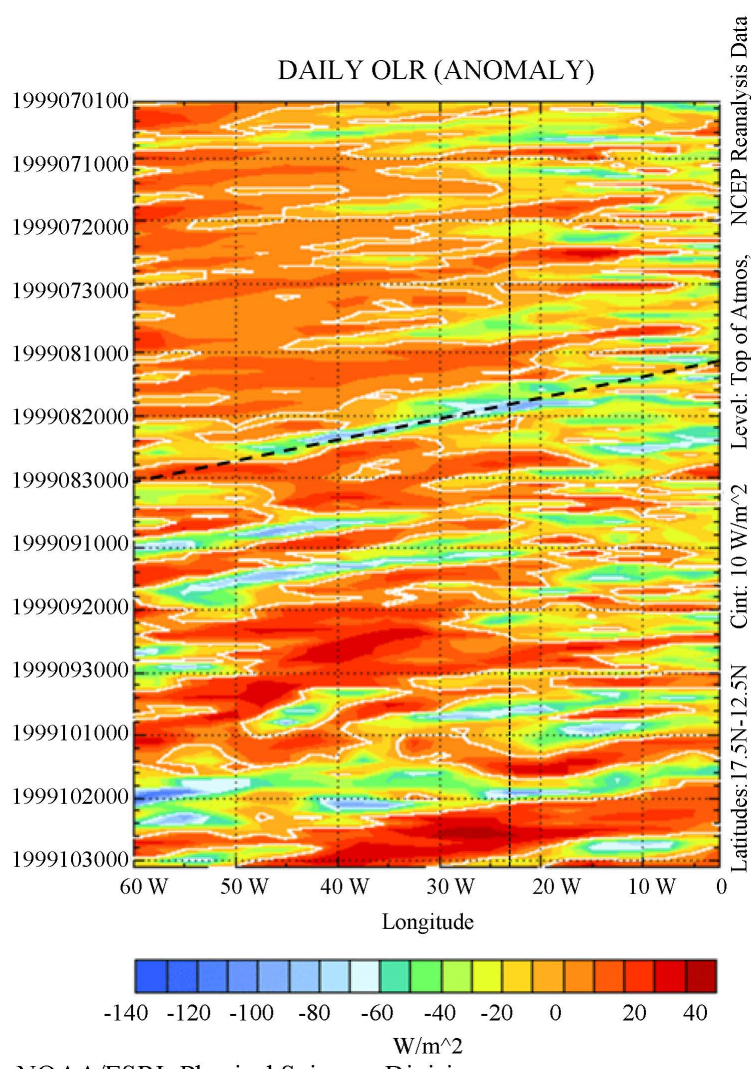

NOAA/ESRL Physical Sciences Division

(b)

Figure 5. Daily outgoing long wave radiation anomalies for (a) 1994 and (b) 1999. Dashed vertical line marks the archipelago location. High negative values (in blue) represent the convective systems.

under the domain of the subtropical high pressure system. Daily anomalies, however, show very distinct picture when comparing the dry and the wet years. In Figure 6(a), it can be seen that positive SLP anomalies dominate almost the entire rainy season in 1994, except for the end of the period. On the other hand, during the wet year (Figure 6(b)), negative anomalies replace the positive ones in the wet season, indicating that the SLP is below normal and associated with rain producing traveling disturbances and not the ITCZ positioning over the archipelago. So, the SLP anomaly analysis supports the results of the OLR anomaly analysis depicted in Figure 5. The question that remains to be clarified is if such disturbances result from the squall lines that leave the African Continent propagating westward.

Figure 7 illustrates the wind component anomaly patterns for $850 \mathrm{hPa}$ level during the year 1994. In Figure 7(a), it is observed that during the year 1994, $\mathrm{U}$ anomalies are mostly positive, indicating that either the wind is a below average easterly wind or a westerly wind, strong westerly in this case, since its magnitude frequently exceeds $10 \mathrm{~m} \cdot \mathrm{s}^{-1}$. If the $\mathrm{V}$ anomalies are positive (Figure 7(b)), then $\mathrm{V}$ is either from the north, with magnitude smaller than the average wind component, or from the south, since northerly winds dominate the region. Thus, considering, $\mathrm{U}$ and $\mathrm{V}$ anomalies both positive, the wind blows from the southwestern quadrant. In general, the $\mathrm{V}$ anomalies remained negative and weak for most of the rainy season, with occasional positive pulses such as around the days 6th-8th of October, a southwesterly wind surge. Notice that the OLR anomalies (Figure 5(a)) and the SLP anomalies (Figure 6(a)) are both negative, indicating convective activity over the archipelago. This suggests that, during the dry year 1994, the predominant wind is from the northeastern quadrant during the wet season. In other word, the wind is dry, coming from the North Africa anticyclone.

In contrast, the year 1999 shows positive anomalies for $U$ and $\mathrm{V}$, with values exceeding $10 \mathrm{~m} \cdot \mathrm{s}^{-1}$ (Figure 8). With both anomalies positive, the $\mathrm{U}$ component is from west and the $\mathrm{V}$ component from the south. In other words, south western quadrant winds are dominant. Again it can be seen that both OLR and SLP anomalies are 


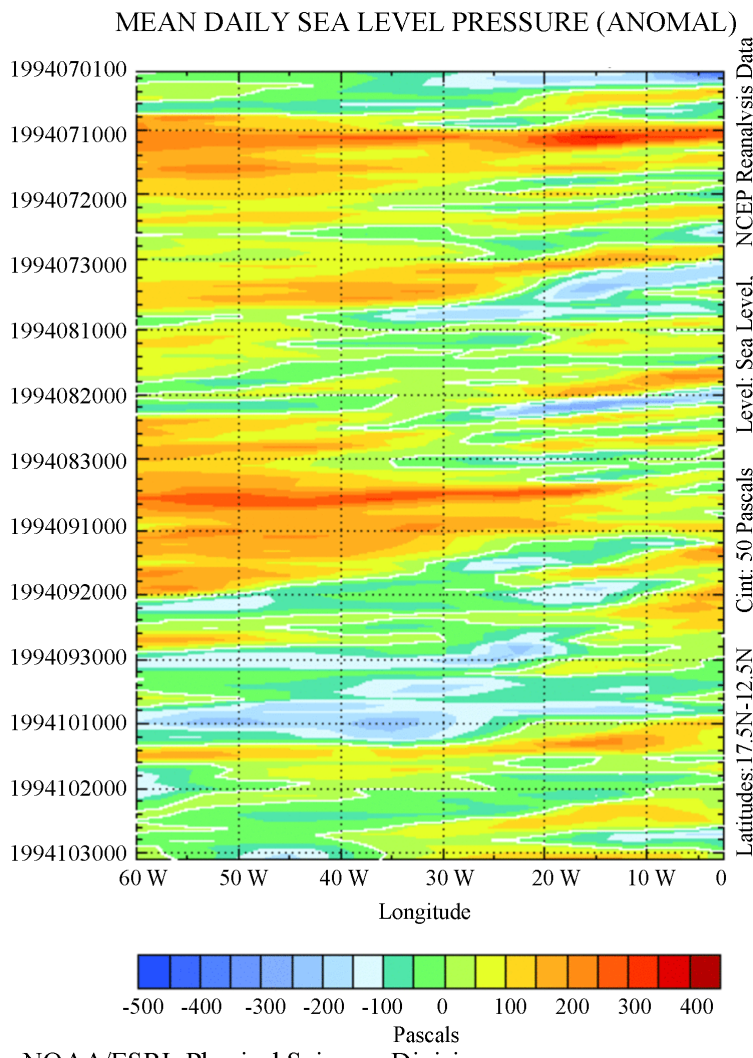

NOAA/ESRL Physical Sciences Division

(a)

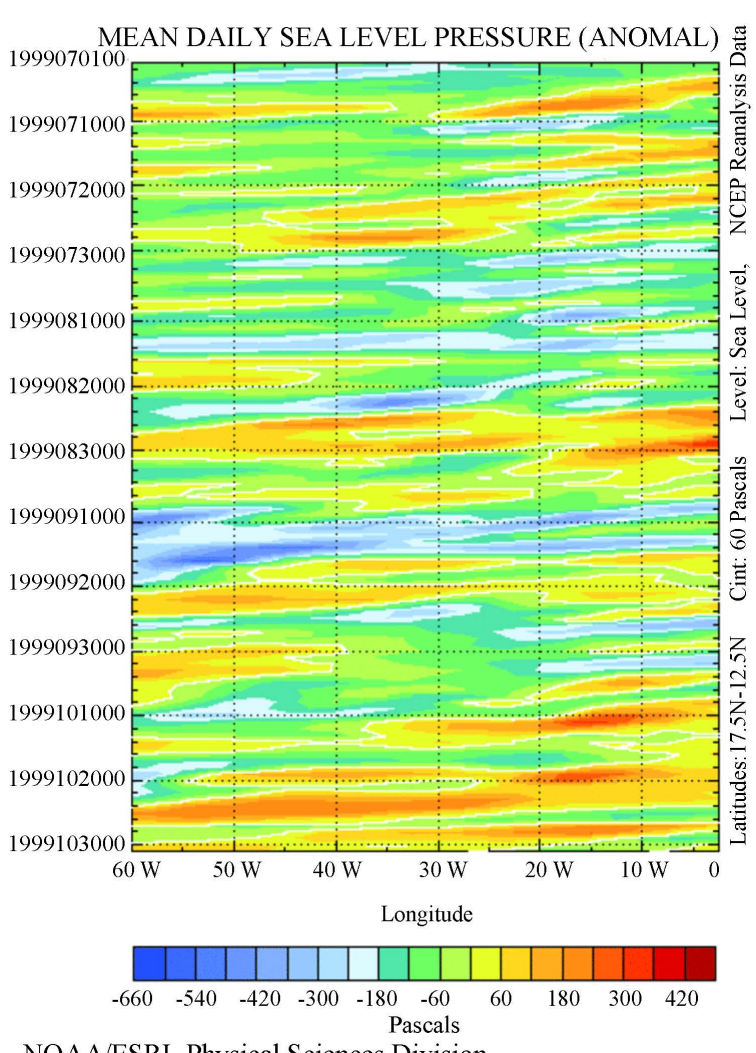

NOAA/ESRL Physical Sciences Division

(b)

Figure 6. Daily sea level pressure anomalies for (a) 1994 and (b) 1999. Dashed vertical line marks the Archipelago location. High negative values (in blue) represent pressure below normal.

negative, indicating convective activity over the region. These results suggest that, during wet year, these winds are intense, persistently blowing over the warm Atlantic Ocean. As they meet the northeasterly trade winds coming out of the subtropical high pressure system, the moisture flux convergence is enhanced so does the precipitation over Cape Verde.

These results present evidences that Santiago rainfall regime is strongly dependent on transient convective weather systems which bring rain over the region but not on the ITCZ or African squall lines. The rain producing systems apparently propagate from the southwestern quadrant and they are associated with the cold fronts that cross the Atlantic coming from North American continent.

\section{Summary and Conclusions}

This paper presents results of long-term analysis of rainfall data collected at the Santiago Island weather stations network of Cape Verde National Institute of Meteorology and Geophysics. The datasets of four stations are analyzed for the period 1981-2009, 29-year records. Rainfall distribution, seasonality and long-term variability are analyzed using monthly and annual averages relative to the study period.

Rainfall over Cape Verde is concentrated in 3 to 4 months (July-October), especially in August and September which, together, are responsible for more than $75 \%$ of the total precipitation. September exhibits the highest accumulated precipitation. The dry season is from November to June (8 months) and it is characterized by sporadic rainfall events, mostly from November to January, discussed as transition months when remnants of cold fronts reach the archipelago. During the transition months, precipitation values are, generally, less than 15 $\mathrm{mm} / \mathrm{month}$. These results clearly show that Santiago has well defined rainfall regime, which is similar to semiarid climate regions. There is a strong evidence of direct influence of orography over the total precipitation, a result in agreement with previous studies. It is worth to point out that there are single months of extreme 


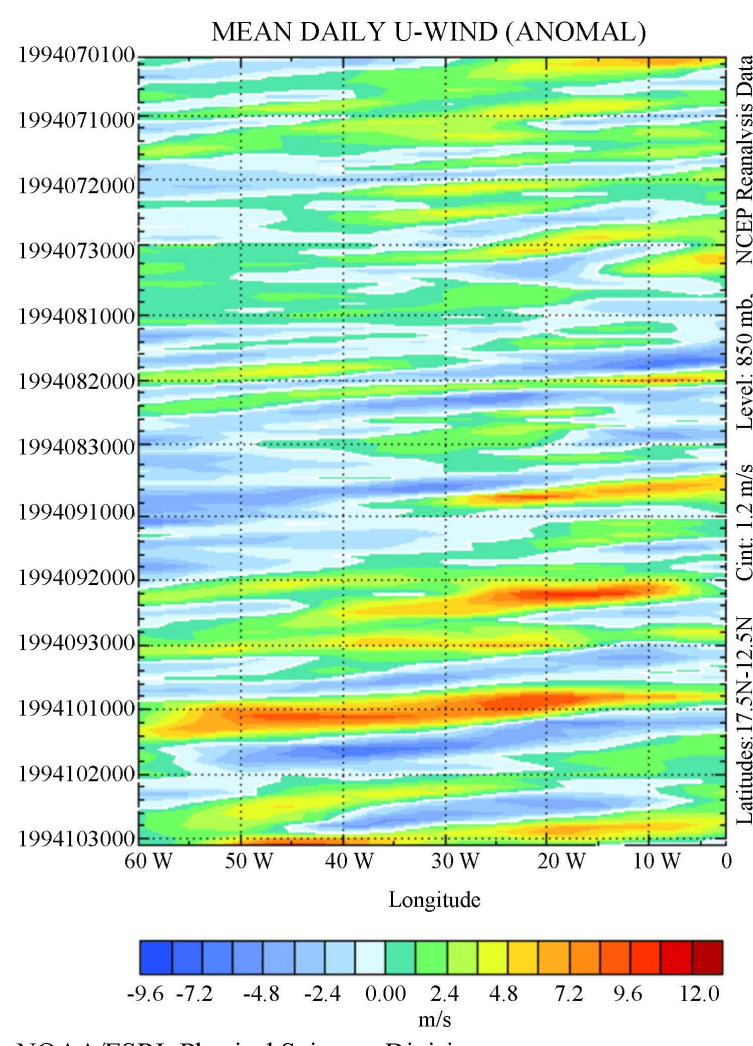

NOAA/ESRL Physical Sciences Division

(a)

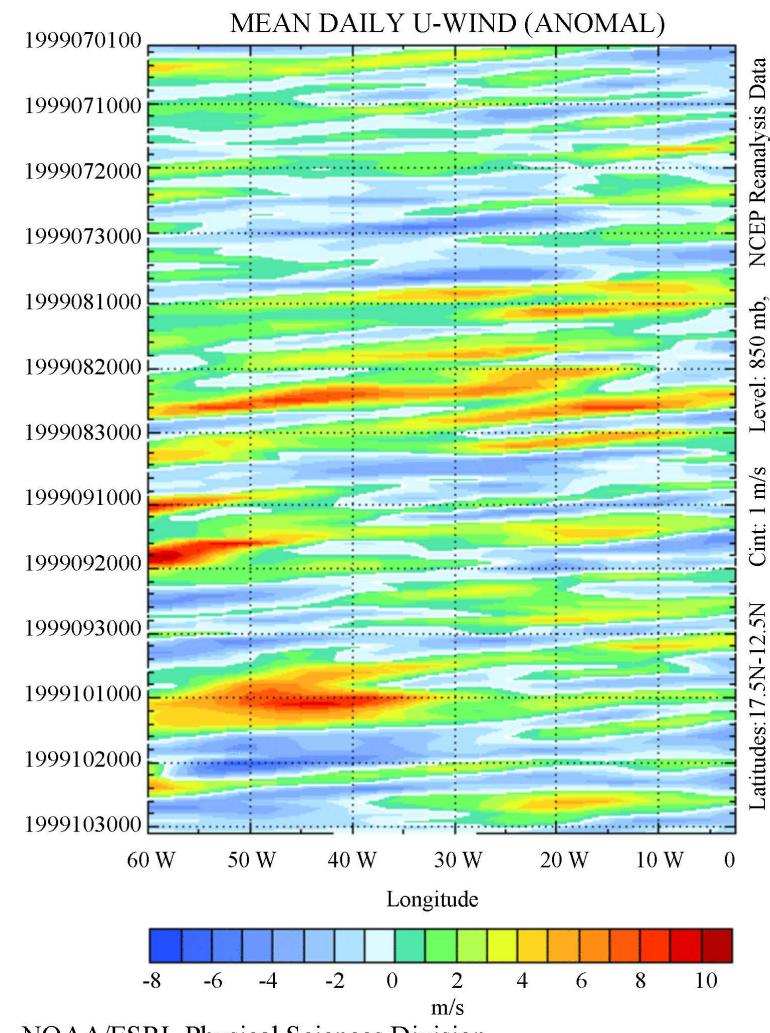

NOAA/ESRL Physical Sciences Division

(b)

Figure 7. Zonal (a) and meridional (b) wind components anomalies for the dry year 1994. Dashed vertical line represents the Archipelago location.

drought within the 29-year period studied.

The OLR anomalies and the SLP anomalies analysis, used as proxies for weather systems propagation, show that most of rain-producing systems that affect Cape Verde are associated with transient convective disturbances. Evidently, traveling disturbances are more frequent and intense during wet years than dry years. Time versus longitude section plots of $\mathrm{U}$ and $\mathrm{V}$ wind components anomalies for 1994, the driest year, indicate that the $\mathrm{V}$ anomalies remained negative and weak for most of the rainy season and occasional positive surges of southwestterly winds were associated with OLR and SLP negative anomalies. In contrast, during 1999 wet year, strong and intense winds, blowing from the southwestern quadrant over Atlantic bring moisture, enhances the convergence flux and, thus, rainfall over the Archipelago. So, these results indicate that rainfall is produced by southwesterly transient disturbances associated with the frontal systems that cross the Atlantic and not with ITCZ or squall lines coming from North Africa.

Standardized rainfall index proved to be an excellent method to identifying the extreme years within the period. The results show that there is strong inter-annual rainfall variability in Cape Verde. However, apparently it is not related with El Niño-Southern Oscillation (ENSO) phenomenon and its cause must be further investigated. This result is a surprise, as West Africa rainfall presents some relation with ENSO (e.g., [21] [22]). The rainfall series was broken into two periods. The first period 1981-1998 coincides with the PDO warm phase. This period has only two years, 1986 and 1987, with rainfall totals above one standard deviation. The other 16 years (89\%), including the driest year, have rainfall either below or near the average. The second period, 1999-2009, is characterized by 7 rainy years out of 11 years, in particular the rainiest year in the whole period. 1999. Only one year was moderately dry (2002), but its departure module is below one standard deviation. In other words, there are no drought conditions during the present PDO cold phase. These results suggest an inter-decadal rainfall variability that may be related to PDO. The North Atlantic Oscillation (NAO) may also be related to the Cape Verde rainfall, but its relationship was not investigated and it may be object of future study. Considering that PDO 


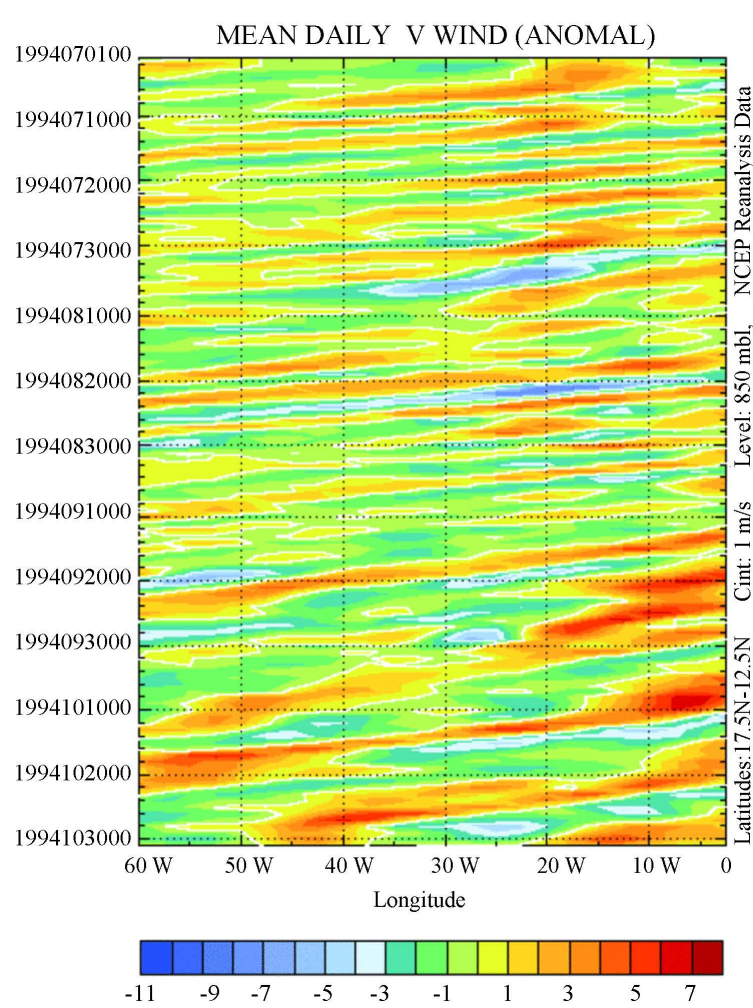

NOAA/ESRL Physical Sciences Division

(a)

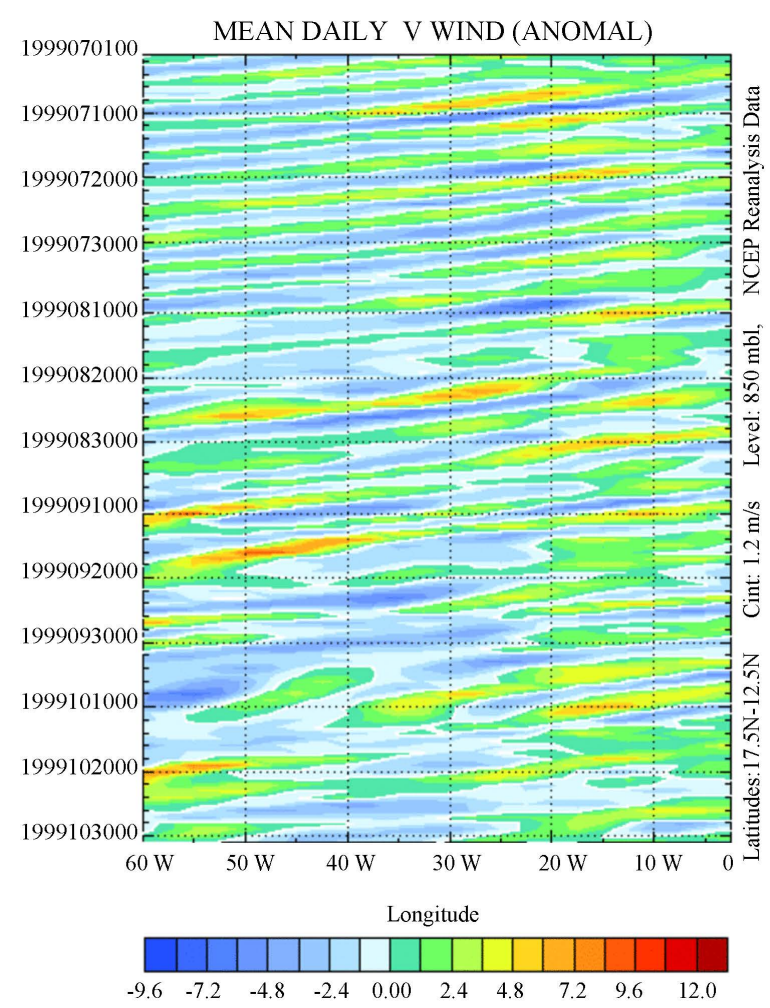

NOAA/ESRL Physical Sciences Division

(b)

Figure 8. Zonal (a) and meridional (b) wind components anomalies for the wet year 1999. Dashed vertical line represents the Archipelago location.

phases last 25 - 30 years and the current phase may go further another 10 to 15 years, it is possible that the severe drought years may decrease in frequency in this near future.

The understanding the genesis of these systems will certainly improve weather and climate forecasting, both short and seasonal term, contributing to developing and implementing policies and strategies for water resources usage in Cape Verde.

\section{Acknowledgements}

The authors acknowledge the contribution of the National Institute of Meteorology of Cape Verde (INMG) for providing the precipitation data. G. E. V-L thanks the Coordenação de Aperfeiçoamento de Pessoal de Nível Superior-CAPES for the financial support.

\section{References}

[1] Thornthwaite, C.W. (1948) An Approach toward a Rational Classification of Climate. Geographical Review, 38, 55-94. http://dx.doi.org/10.2307/210739

[2] Da Rocha Faria, J.M. (1971) Frequency Analysis of the Annual Highest Values of the Daily Precipitation in Some Portuguese Overseas sites. Fomento (Lisbon), 9, 237-270.

[3] Babau, M.C. (1983) Evolution de la pluie annuelle de 1885 à 1993 à la station de Praia, Ile de Santiago, Cap Vert. Document de travail project Agrhymet: OMM/RAF/78/004 de l’Organization Météorologique Mondiale des Nations Unies. Ministere de Developpement Rural, Praia.

[4] Hastenrath, S. (1985) Climate and Circulation of the Tropics. D. Reidel, Dordrecht, 455 p. http://dx.doi.org/10.1007/978-94-009-5388-8

[5] Wu, X., Liang, X.-Z. and Zhang, G.J. (2003) Seasonal Migration of ITCZ Precipitation across the Equator: Why Can’t 
GCMs Simulate It? Geophysical Research Letters, 30, 1824. http://dx.doi.org/10.1029/2003GL017198

[6] Motha, R.P., Leduc, S.K., Steyaert, L.T., Sakamoto, C.M. and Strommen, N.D. (1980) Precipitation Patterns in West Africa. Monthly Weather Review, 108, 1567-1578. http://dx.doi.org/10.1175/1520-0493(1980)108<1567:PPIWA>2.0.CO;2

[7] Sultan, B. and Janicot, S. (2000) Abrupt Shift of the ITCZ over West Africa and Intra-Seasonal Variability. Geophysical Research Letters, 27, 3353-3356. http://dx.doi.org/10.1029/1999GL011285

[8] Meier, F. and Knippertz, P. (2009) Dynamics and Predictability of a Heavy Dry-Season Precipitation Event over West Africa Sensitivity Experiments with a Global Model. Monthly Weather Review, 137, 189-206. http://dx.doi.org/10.1175/2008MWR2622.1

[9] Aspliden, C.I. and Adefolalu, D. (1976) The Mean Troposphere of West Africa. Journal of Applied Meteorology, 15, 705-716. http://dx.doi.org/10.1175/1520-0450(1976)015<0705:TMTOWA>2.0.CO;2

[10] Ogallo, L. (1979) Rainfall Variability in Africa. Monthly Weather Review, 107, 1133-1139. http://dx.doi.org/10.1175/1520-0493(1979)107<1133:RVIA>2.0.CO;2

[11] Lucio, P.S., Molion, L.C.B., Conde, F.C. and Melo, M.L.D. (2012) A Study on the West Sahel Rainfall Variability: The Role of the Intertropical Convergence Zone (ITCZ). African Journal of Agricultural Research, 7, 2096-2113. http://dx.doi.org/10.5897/AJAR11.627

[12] Carreira, P.M., Marques, J.M., Pina, A., Gomes, A.M., Fernandes, P.A.G. and Santos, F.M. (2010) Groundwater Assessment at Santiago Island (Cabo Verde): A Multidisciplinary Approach to a Recurring Source of Water Supply. Water Resource Management, 24, 1139-1159. http://dx.doi.org/10.1007/s11269-009-9489-z

[13] Mota Gomes (2007) Hidrogeologia e recursos hídricos da ilha de Santiago—Cabo Verde. Ph.D. Dissertation, University of Aveiro, Aveiro, 269 p. (in Portuguese)

[14] Mannaerts, C.M. and Gabriels, D. (2000) Rainfall Erosivity in Cape Verde. Soil \& Tillage Research, 55, $207-212$. http://dx.doi.org/10.1016/S0167-1987(00)00104-5

[15] Amaral, I. (1964) Santiagode Cabo Verde: A Terra e os Homens. Memórias, 48, 444 p.

[16] World Meteorological Organization (2011) Guide to Climatological Practices. 3rd Edition, World Meteorological Organization, Geneva.

[17] Nicholson, S.E. (1979) Revised Rainfall Series for the West African Subtropics. Monthly Weather Review, 107, 620623. http://dx.doi.org/10.1175/1520-0493(1979)107<0620:RRSFTW>2.0.CO;2

[18] Kalnay, E. and Coauthors (1996) The NCEP/NCAR Reanalysis 40-Year Project. Bulletin of the American Meteorological Society, 77, 437-471. http://dx.doi.org/10.1175/1520-0477(1996)077<0437:TNYRP>2.0.CO;2

[19] Liebmann, B. and Smith, C.A. (1996) Description of a Complete (Interpolated) Outgoing Longwave Radiation Dataset. Bulletin of the American Meteorological Society, 77, 1275-1277.

[20] Le Barbé, L., Lebel, T. and Tapsoba, D. (2002) Rainfall Variability in West Africa during the Years 1950-90. Journal of Climate, 15, 187-202. http://dx.doi.org/10.1175/1520-0442(2002)015<0187:RVIWAD>2.0.CO;2

[21] Nicholson, S.E., Some, B. and Kone, B. (2000) An Analysis of Recent Rainfall Conditions in West Africa, Including the Rainy Seasons of the 1997 El Niño and the 1998 La Niña Years. Journal of Climate, 13, 2628-2640. http://dx.doi.org/10.1175/1520-0442(2000)013<2628:AAORRC>2.0.CO;2

[22] Molion, L. and Lucio, P. (2013) A Note on Pacific Decadal Oscillation, El Niño Southern Oscillation, Atlantic Multidecadal Oscillation and the Intertropical Front in Sahel, Africa. Atmospheric and Climate Sciences, 3, 269-274. http://dx.doi.org/10.4236/acs.2013.33028 
Scientific Research Publishing (SCIRP) is one of the largest Open Access journal publishers. It is currently publishing more than 200 open access, online, peer-reviewed journals covering a wide range of academic disciplines. SCIRP serves the worldwide academic communities and contributes to the progress and application of science with its publication.

Other selected journals from SCIRP are listed as below. Submit your manuscript to us via either submit@scirp.org or Online Submission Portal.
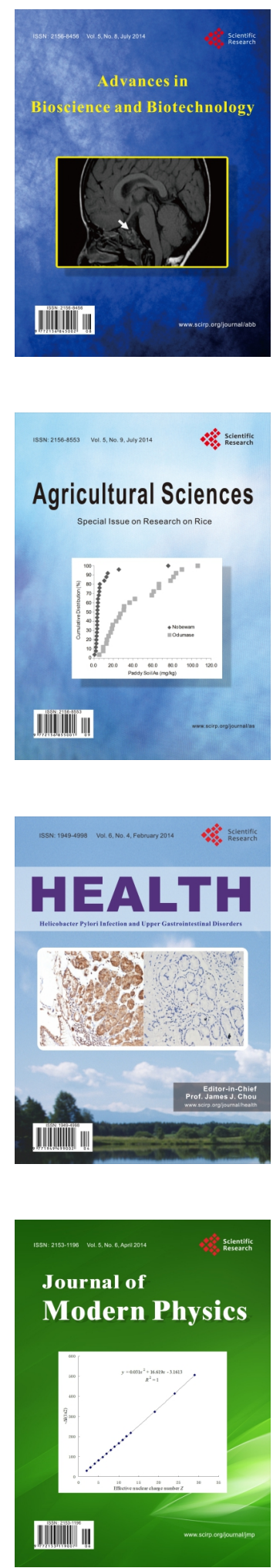
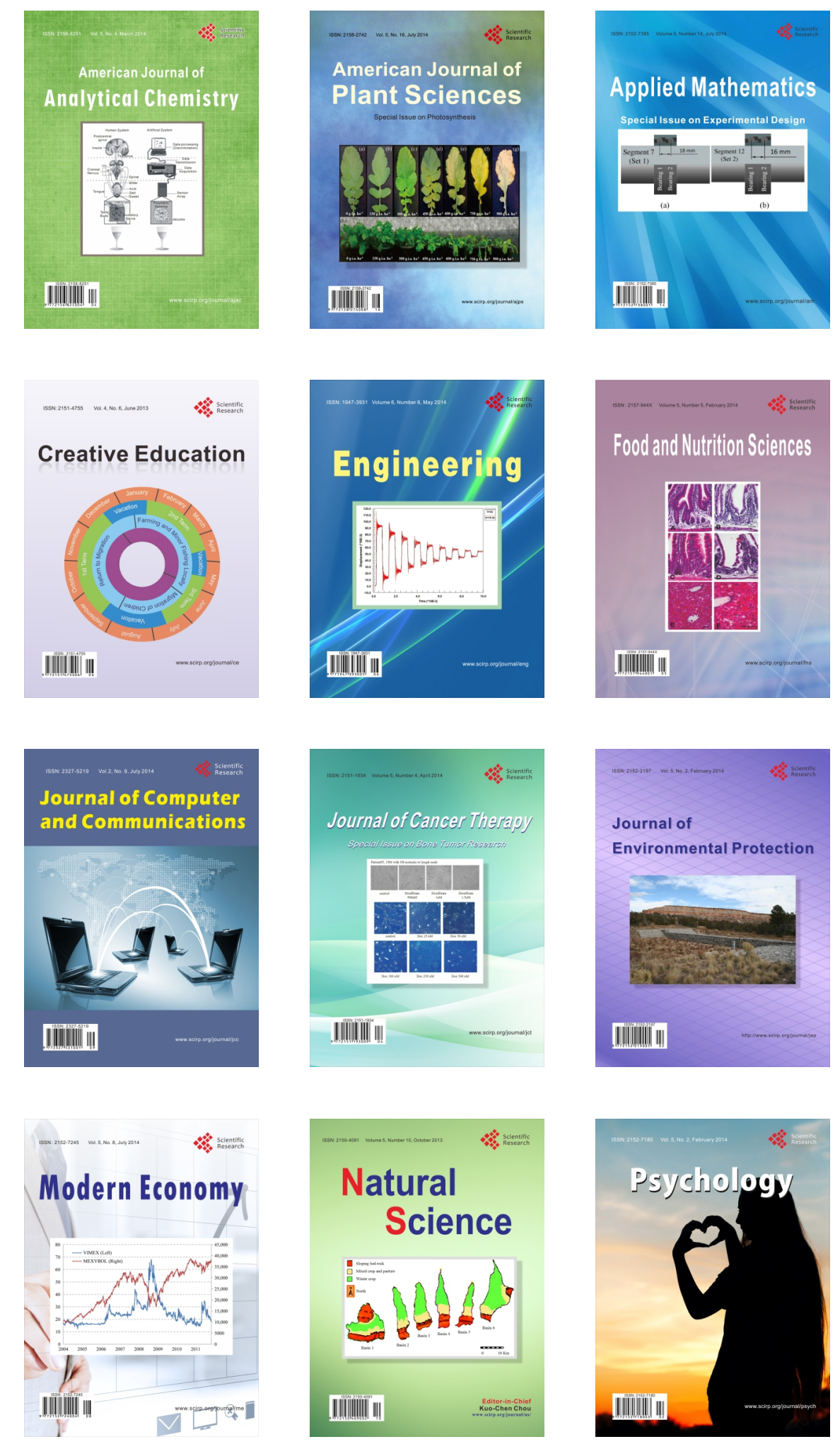